\title{
Quality assessment and safety measurement of different industrial processing stages of soybean oil
}

\author{
Nasrullah Syed ${ }^{1 *}$, Sarfaraz Ahmed Mahesar ${ }^{2}$, Syed Tufail Hussain Sherazi ${ }^{2}$, Mustafa Soylak ${ }^{1}$ \\ ${ }^{1}$ Erciyes University, Science Faculty, Department of Chemistry, 38039, Kayseri, Turkey \\ ${ }^{2}$ National Centre of Excellence in Analytical Chemistry, University of Sindh, Jamshoro, 76080, Pakistan
}

\begin{abstract}
The impact of industrial processing on physical and chemical properties as well as fatty acid composition of soybean oil (SBO) was analyzed. These physicochemical parameters were tested by standard (IUPAC and AOCS) methods. The observed results of physical properties showed that, at some stages in neutralization, bleaching and deodorization of crude SBO, the value of the freezing point, color, moisture content and smoke point greatly decreased whereas a slight reduction in refractive index was obtained. Likewise, in the instance of chemical parameters, saponification value, free fatty acids, peroxide value and iodine value were decreased from 177.0 to $176.1 \mathrm{mg} \mathrm{KOH} / \mathrm{g}$ oil, 1.26 to $0.05 \%, 3.5$ to 1.8 $\mathrm{mEq} \mathrm{O}_{2} / \mathrm{kg}$ oil and 125.0 to $124.1 \mathrm{~g} \mathrm{I}_{2} / 100 \mathrm{~g}$ of oil, correspondingly. Refining processing did not obtain major impact on the fatty acid composition. During chemical neutralization step, soap contents were generated. Consequently, soap content was reduced from 61.0 to $15.2 \mathrm{ppm}$ in bleaching and deodorization stages. Additionally, this study indicates that overall deodorization step has significant influence on physicochemical parameters to enhance the quality, stability and safety measurement of soybean oil.
\end{abstract}

\section{ARTICLE HISTORY}

Received: 25 September 2019

Accepted: 13 December 2019

\section{KEYWORDS}

Soybean oil

Physicochemical properties

Fatty acid composition

\section{* CORRESPONDING}

nasrullah_sayed@yahoo.com

\section{Introduction}

The world-wide commercially importance of oil namely soybean cultivation (Glycine $\max$ L.) is largely $35-50 \%$ protein and 15-25\% oil content of the seed (Nichols et al., 2006; Hurburgh, 1994). Soybean is an important source of food, protein and oil (Pagano and Miransari, 2016). The world's production over 319.36 million metric tons an annually based including the USA, Brazil, Argentina, China and India (USDA, 2015). However, purifying oil and protein substances are significant objects of consumption for animal feed and human food (Nichols et al., 2006). Afterwards, oil and protein concentrations were inversely related to the contents of seeds cultivated in vivo (Wilcox and Shibles, 2001; Hyten et al., 2004).

However, physicochemical properties, oxidative stability and fatty acid composition determine nutritional value of vegetable oil (Mahesar et al., 2017). Crude soybean oil is unacceptable for the usage in most of the food products without processing, because of its odor, dark color, objectionable flavor and high free fatty acid content.

Unwanted constituents such as peroxides, color pigments and free fatty acids have adverse influence on storage stability, physicochemical parameters and sensory characteristics of the oil. Some physicochemical refining steps consisting crude, neutralization, bleaching and deodorization have been usually shown to remove these impurities and to obtain oxidatively stable, odorless, bland oils which are suitable to consumers and maintain quality (Farhoosh et al., 2009).

Most of the free fatty acids are removed in chemical refining during alkali neutralization process. Whereas, free fatty acids in oils are removed in physical refining during deodorization process (Alpaslan et al., 2001). Not only physicochemical refining processes line are seemly to maintain the quality and stability of oil, but also these processing steps eliminate some important nutritionally components form the oil as well (Gogolewski et al., 2000).

The main objective of present work was to determine the impact of industrially chemical refining stages such as crude, neutralization, bleaching and deodorization on some physicochemical properties of soybean oil in Pakistan and to draw the focus of concerned authorities and consumers regarding the consequences of its low quality. For the best of our information, no any work has been reported so far on the physicochemical properties of soybean oil during industrial refining.

\section{Materials and methods}

\subsection{Chemicals and oil samples}

All the materials and reagents used in the recent study were purchased from (E-Merck Dermstadt) Germany. Soybean oil samples (crude, neutralized, bleached and deodorized) were collected from the industrial processing steps in commercial oil industry located at Hyderabad, Pakistan. These
ORCID

Nasrullah Syed: https://orcid.org/0000-0003-4077-3406

Sarfaraz Ahmed Mahesar: https://orcid.org/0000-0003-2120-9623
Syed Tufail Hussain Sherazi: https://orcid.org/0000-0003-0210-2759

Mustafa Soylak: https://orcid.org/0000-0002-1017-0244 
representative samples were stored in darkful glass vessels, purged with gas as nitrogen and after adding, stored at $4{ }^{\circ} \mathrm{C}$ to decrease the oxidation till analysis.

\subsection{Physicochemical parameters}

Physicochemical properties of industrially processed soybean oils were measured according to the American Oil Chemists Society (AOCS) methods (Firestone, 2009) such as moisture, color, freezing point $\left({ }^{\circ} \mathrm{C}\right)$, smoke point $\left({ }^{\circ} \mathrm{C}\right)$, refractive index $\left(40^{\circ} \mathrm{C}\right)$, iodine value, free fatty acids, peroxide value, saponification value and fatty acids composition.

\subsection{Moisture}

Moisture content in the industrially processed soybean oil was checked by oven method at $105^{\circ} \mathrm{C} \pm 1^{\circ} \mathrm{C}$ for 1 hour using Moisture Analyzer MX-50 (SHS) Super Hybrid Sensor by applying AOCS method Da 2a-48 (Firestone, 2009).

\subsection{Color}

The color of industrially processed soybean oil was determined in terms of Lovibond units using AOCS method Cc 13a-43 (Firestone, 2009). Before checking of color, glass cell (1 inch and 5 1/4 inch) was washed, cleaned and dried, and it was followed by the measuring of color using Lovibond Tintometer (Model F). The color was matched by sliding the red, yellow and blue color of the Lovibond Tintometer glasses until a perfect match was obtained while observing through the eye piece (pin hole).

\subsection{Freezing and smoke point}

For freezing point approximately $50 \mathrm{~g}$ of oil sample was taken and kept in the upper portion of refrigerator for 30 minutes at 2 to $3^{\circ} \mathrm{C}$ according to AOCS method Cc 9a-47 (Firestone, 2009). Whereas, smoke point was observed by using AOCS (Cc 9a-48) method (Firestone, 2009). Briefly $50 \mathrm{~mL}$ of oil was kept on heating mental at above $175^{\circ} \mathrm{C}$ for 1 hour.

\subsection{Refractive index}

The refractive index is defined as the ratio of speed of light in the substance to the speed of light in a vacuum. The refractive index of soybean oil was carried out at $40^{\circ} \mathrm{C} \pm 1$ according to AOCS method Cc-7-25 (Firestone, 2009) using Refractometer.

\subsection{Free fatty acids}

Free fatty acid in industrially processed soybean oil was determined by titration method using AOCS method Da 1448 (Firestone, 2009). Briefly, oil was dissolved in warm neutralized ethanol and shaken vigorously. The mixture solution was titrated in the presence of phenolphthalein indicator against $0.1 \mathrm{~N}$ sodium hydroxide solution.

\subsection{Saponification value}

Approximately $2 \mathrm{~g}$ of edible oil was added in a round bottom flask and added $25 \mathrm{~mL}$ of alcoholic potassium hydroxide. The material was refluxed at water bath for one hour until reaction completed. After cooling of mixture, $1 \mathrm{~mL}$ of indicator as a phenolphthalein was added to it and titrated against $0.5 \mathrm{~N}$ of hydrochloric acid until discoloration of the pink color. Similarly, a blank test was also carried out in the same manner except the presence of oil using AOCS method
Da 16-48 (Firestone, 2009).

\subsection{Iodine value}

The amount in grams of iodine absorbed by 100 gram of oil is known as IV. Approximately $0.1 \mathrm{~g}$ oil was dissolved into carbon tetrachloride $(7.5 \mathrm{~mL})$ followed by Wijis reagent $(12.5 \mathrm{~mL})$ and inserted the stopper. The solution was shaken gently and placed in the dark for 1 hour. After that, fresh solution of $7.5 \mathrm{~mL}$ potassium iodide and $75 \mathrm{~mL}$ pour water was added and then few drops of starch indicator were added. Liberated iodine from mixture solution was then titrated against $(0.1 \mathrm{~N})$ standard sodium thiosulphate solutions until the blue color disappeared at end point. Similarly, a blank test was also carried out in the same manner excluding the presence of oil by Wijis method, AOCS Cd Ib-87 (Firestone, 2009).

\subsection{Peroxide value}

Approximately $2 \mathrm{~g}$ of oil was weighed in conical flask and added $10 \mathrm{~mL}$ chloroform and stirred. After that, $15 \mathrm{~mL}$ of glacial acetic acid and $1 \mathrm{~mL}$ of potassium iodide were added and shaked well for 1 minute and the solution was kept in dark for 5 minutes. Flask was removed from the dark and added $75 \mathrm{~mL}$ water along with starch indicator of 2 to 3 drops. The solution mixture was titrated against $0.01 \mathrm{~N}$ sodium thiosulphate. Similarly, a blank test was also carried out in the same manner without the presence of oil according to AOCS method (Cd 8- 53) (Firestone, 2009).

\subsection{Soap content}

Approximately $10 \mathrm{~g}$ of CSO was weighed in conical flask, added $10 \mathrm{~mL}$ acetone and then poured 3 drops of bromophenol as an indicator. That mixture of solution was titrated against $0.01 \mathrm{~N}$ hydrochloric acid till reddish green color changed to yellow color and soap contents were calculated by the formula as reported in AOCS Cc 17-95 method (Firestone, 2009).

\subsection{Fatty acid composition analysis}

IUPAC standard 2.301 methods were used to prepare fatty acid methyl esters (FAMEs) of SBO (Paquot and Hautfenne, 1987). Studies of FAMEs of soybean oils were done by using gas chromatography instrument coupled with GC-MS containing mass selective detector as model $6890 \mathrm{~N}$ from Agilent Technology. ChemStation software with Mode Scale (6890) was operated for the analysis of chromatographic peak. A capillary HP-5MS column with 30 $\mathrm{m} \times 0.25 \mathrm{~mm}$ ID $\times 0.25 \mu \mathrm{m}$ film thickness, $5 \%$ phenyl methylsiloxane was used for the separation of fatty acid composition. The starting oven temperature was $150^{\circ} \mathrm{C}$; after 2 minutes it then increased up to $230^{\circ} \mathrm{C}$ with $4^{\circ} \mathrm{C} / \mathrm{min}$ ramp rate. Helium gas was used as the carrier gas with $0.8 \mathrm{~mL} / \mathrm{min}$ flow rate. Injector temperature was selected at $240^{\circ} \mathrm{C}$, for detector temperature at $260^{\circ} \mathrm{C} .1 \mu \mathrm{L}$ each sample was inserted as split mode ratio 50:1. All analysis was performed in triplicate.

\subsection{Statistical analysis}

The soybean samples were analyzed in triplicate. Data was reported as Means \pm Standard deviation $n=3 \times 3$. 


\section{Results and discussion}

3.1. Physical parameters of industrially processed soybean oil

The physical parameters of crude, neutralized, bleached and deodorized soybean oil samples were collected from the edible oil industry located at Hyderabad, Pakistan. Results of moisture, color, freezing point, smoke point and refractive index of crude SBO and after each processing stage are shown in Table 1.

\subsection{Moisture}

It is well known fact that oil free from moisture has advantage in terms of oxidative stability, since higher the moisture content lowers the storability and suitability of oil preservation for a longer period. During neutralization, moisture in crude soybean oil was decreased from 0.38 to $0.24 \%$ with the level of $36.84 \%$. In the stage of bleaching, moisture was further reduced from 0.24 to $0.03 \%$ by the level of $87.50 \%$. While deodorization process decreased the moisture level of bleached oil from 0.03 to $0.01 \%$ with $0.39 \%$ removal efficiency. Overall performance of neutralization, bleaching and deodorization for the reduction of moisture level was found to be $16.27,40.70$ and $43.03 \%$, respectively.

\subsection{Color}

Chlorophyll, carotenoids and some other pigments are responsible for the color of the oil. The tintometer is often operated to differentiate in terms of red (R) and yellow (Y) color units of oil. Color of crude oil is usually measured in 1 inch cell whereas color of bleached and deodorized is evaluated in 5.25 inch cell. Alkali neutralization significantly reduced from 4.0 to $3.0 \mathrm{R}$ and 40.0 to $30 \mathrm{Y}$, which indicated that $25 \%$ and $25 \%$ loss of oil color. In bleaching stage, color was reduced from 3.0 to $2.8 \mathrm{R}$ and 30.0 to $28.0 \mathrm{Y}$, which showed $3.12 \%$ and $3.12 \%$ color removal during bleaching. In deodorization process, the oil color further reduced from 2.8 to $1.2 \mathrm{R}$ and 28.0 to $12.0 \mathrm{Y}$, which illustrated $40.0 \%$ and $40.0 \%$ reduction in color. Overall outcomes of industrial process on neutralization, bleaching and deodorization was found to be $20.0 \% \mathrm{R}, 20.0 \% \mathrm{Y}, 24.0 \% \mathrm{R}, 24.0 \% \mathrm{Y}$ and $56.0 \% \mathrm{R}, 56.0 \% \mathrm{Y}$, respectively. The color intensity of vegetable oils, mostly removed during bleaching and deodorization process. Vegetable oils with light color intensity are recognized to be more engaging from commercial view-point (Ali et al., 2009).

Table 1. Physical properties of crude and industrially processed soybean oils

\begin{tabular}{lllll}
\hline Parameters & Crude SBO & Neutralized SBO & Bleached SBO & Deodorized SBO \\
\hline Moisture $(\%)$ & $0.38 \pm 0.07$ & $0.24 \pm 0.09$ & $0.03 \pm 0.08$ & $0.01 \pm 0.04$ \\
\hline Color & & & & \\
\hline Red units & $4.0 \pm 0.65 \mathrm{R}$ & $3.0 \pm 0.25 \mathrm{R}$ & $2.8 \pm 0.59 \mathrm{R}$ & $1.2 \pm 0.67 \mathrm{R}$ \\
Yellow Units & $40.0 \pm 0.60 \mathrm{Y}$ & $30.0 \pm 0.35 \mathrm{Y}$ & $28.0 \pm 0.56 \mathrm{Y}$ & $12.0 \pm 0.66 \mathrm{Y}$ \\
\hline Freezing point $\left({ }^{\circ} \mathrm{C}\right)$ & $6.5 \pm 0.32^{\circ} \mathrm{C}$ & $6.1 \pm 0.62{ }^{\circ} \mathrm{C}$ & $5.7 \pm 0.73{ }^{\circ} \mathrm{C}$ & $4.5 \pm 0.77{ }^{\circ} \mathrm{C}$ \\
Smoke point $\left({ }^{\circ} \mathrm{C}\right)$ & $229.0 \pm 0.78^{\circ} \mathrm{C}$ & $225.0 \pm 0.51^{\circ} \mathrm{C}$ & $223.0 \pm 0.68^{\circ} \mathrm{C}$ & $220.0 \pm 0.84^{\circ} \mathrm{C}$ \\
Refractive Index $\left(40^{\circ} \mathrm{C}\right)$ & $1.4735 \pm 0.0014$ & $1.4737 \pm 0.0015$ & $1.4738 \pm 0.0017$ & $1.4739 \pm 0.0019$ \\
\hline
\end{tabular}

\subsection{Freezing point}

The saturated fatty acids content, waxes and triglycerides are typically cause of sediment production and resist flowing oil easily. Therefore, freezing point is a key indicator to measure it. During soybean oil refining, it was observed that in neutralization, bleaching and deodorization stages freezing point of crude oil was decreased from 6.5 to $6.1^{\circ} \mathrm{C}(6.15 \%)$, 6.1 to $5.7 \mathrm{oC}(6.55 \%)$ and 5.7 to $4.5^{\circ} \mathrm{C}$ (21.05\%), correspondingly. Overall input of neutralization, bleaching and deodorization was found to be 12.40, 25.10 and $62.50 \%$, respectively, which clearly showed that deodorization had the major effect on freezing point.

\subsection{Smoke point}

Simply, it can be defined as the temperature at which oil generates continuous thin stream of smoke when heated. Smoke point of oil characterizes appropriateness for frying purpose. During industrial process, it was noticed that smoke point of crude oil was decreased from 229.0 to $225.0 \mathrm{oC}$ for neutralization, 225.0 to $223.0 \mathrm{oC}$ for bleaching and 223.0 to $220^{\circ} \mathrm{C}$ for deodorization stages. Overall input of neutralization, bleaching and deodorization was found to be $20.98,31.60$ and $47.40 \%$, respectively.

\subsection{Refractive index}

The refractive index depends on the triglyceride and fatty acid composition of oil and fat. During analysis it was observed that refining had negligible effect on all stages, although small variation was noticed from crude to neutralization and bleaching to deodorization as 1.4735 to $1.4737,1.4738$ to 1.4739 , respectively. Overall effect on refractive index in terms of percentage was observed in the order of $22.16,33.34$ and $44.50 \%$, respectively for neutralization, bleaching and deodorization.

\subsection{Chemical parameters of industrially processed soybean oil}

Chemical parameters are very important for the quality characteristics of edible oil. These parameters are largely essential for the edible point of view as well as industrial uses. Different chemical properties of SBO were checked during the course of refining process as shown in Table 2. The parameters include saponification value $(\mathrm{SV})$, iodine value (IV), free fatty acid (FFA), peroxide value (PV) and soap content (SC). 


\subsection{Free fatty acids (FFA)}

Free fatty acids (FFA) are not chemically attached to glycerol molecules of fatty acids. This parameter is very significant indicator to show either edible or not edible oils. FFA adversely affect the oxidative stability, taste and odor of oil. FFA contents in edible oil are usually removed or decreased by chemical and/or physical refining (Aluyor et al., 2009). During different refining stages, noticeable change in the reduction of FFA was observed in neutralization (Verleyen et al., 2002), bleaching and deodorization stages. FFA in crude soybean oil were varied from 1.26 to $0.11 \%(91.26 \%)$ reduced in neutralization stage, 0.11 to $0.22 \%(1.24 \%)$ increased in bleaching stage and 0.22 to $0.05 \%(77.27 \%)$ reduces in deodorization stage. If we look at the overall impact on FFA during refining, it can be suggested that all stages have almost equal share for neutralization, bleaching and deodorization as 33.82, 30.58 and $35.60 \%$, respectively.

Table 2. Chemical properties of commercially processed soybean oils

\begin{tabular}{|c|c|c|c|c|}
\hline Parameters & Crude SBO & Neutralized SBO & Bleached SBO & Deodorized SBO \\
\hline Free Fatty Acids (\%) & $1.26 \pm 0.23$ & $0.11 \pm 0.05$ & $0.22 \pm 0.06$ & $0.05 \pm 0.07$ \\
\hline $\begin{array}{l}\text { Saponification Value } \\
\text { (mg KOH/g of oil) }\end{array}$ & $177.0 \pm 0.89$ & $176.5 \pm 0.82$ & $176.3 \pm 0.89$ & $176.1 \pm 0.92$ \\
\hline $\begin{array}{l}\text { Iodine Value } \\
\text { ( } \mathrm{g} \mathrm{I}_{2} / 100 \mathrm{~g} \text { of oil) }\end{array}$ & $125.0 \pm 0.66$ & $124.5 \pm 0.85$ & $124.2 \pm 0.77$ & $124.1 \pm 0.71$ \\
\hline $\begin{array}{l}\text { Peroxide Value } \\
(\mathrm{mEq} \mathrm{O} / \mathrm{kg} \text { of oil })\end{array}$ & $3.5 \pm 0.52$ & $2.9 \pm 0.37$ & $2.0 \pm 0.56$ & $1.8 \pm 0.66$ \\
\hline Soap Content (ppm) & --- & $61.0 \pm 0.91$ & $31.4 \pm 0.86$ & $15.2 \pm 0.88$ \\
\hline
\end{tabular}

Table 3. Fatty acid composition of industrially processed soybean oils

\begin{tabular}{lcccc}
\hline Fatty Acids (\%) & Crude SBO & Neutralized SBO & Bleached SBO & Deodorized SBO \\
\hline Myristic (C14:0) & $0.39 \pm 0.09$ & $0.25 \pm 0.08$ & $0.18 \pm 0.02$ & $0.16 \pm 0.01$ \\
Palmitic acid (C16:0) & $25.65 \pm 0.45$ & $25.55 \pm 0.56$ & $25.35 \pm 0.77$ & $25.31 \pm 0.44$ \\
Palmitoleic acid (C16:1) & $0.32 \pm 0.03$ & $0.25 \pm 0.01$ & $0.20 \pm 0.02$ & $0.17 \pm 0.06$ \\
Stearic acid (C18:0) & $1.05 \pm 0.69$ & $0.90 \pm 0.04$ & $0.89 \pm 0.08$ & $0.73 \pm 0.05$ \\
Oleic acid (C18:1) & $13.87 \pm 0.55$ & $14.10 \pm 0.53$ & $13.98 \pm 0.33$ & $13.80 \pm 0.67$ \\
Linoleic acid (C18:2) & $58.83 \pm 0.86$ & $58.72 \pm 0.78$ & $59.48 \pm 0.99$ & $59.32 \pm 1.04$ \\
Linolenic acid (C18:3) & $0.05 \pm 0.03$ & $0.03 \pm 0.01$ & $0.02 \pm 0.07$ & $0.01 \pm 0.04$ \\
Total Saturated & 27.58 & 26.73 & 26.44 & 26.21 \\
Fatty Acids & 72.42 & 73.27 & 73.56 & 73.89 \\
Total Unsaturated & & & & \\
Fatty Acids & & & & \\
\hline
\end{tabular}

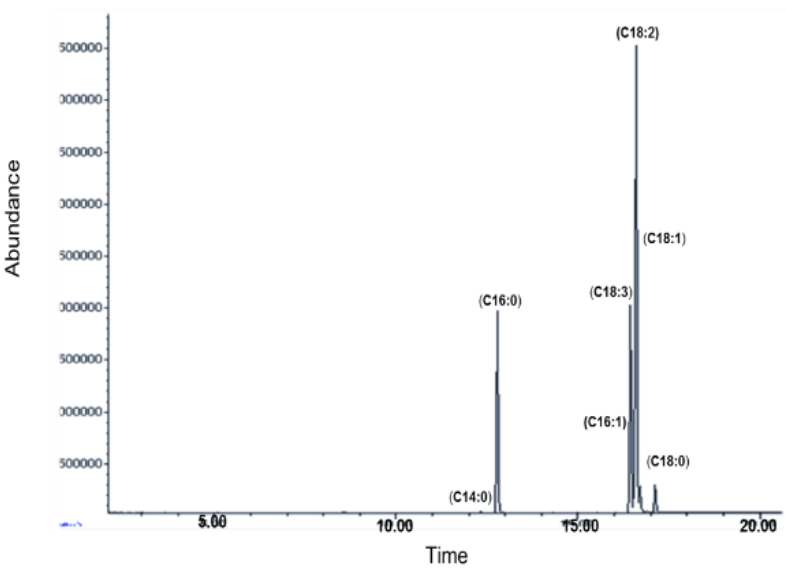

Figure 1. Fatty acid (GC-MS) chromatogram of soybean oil

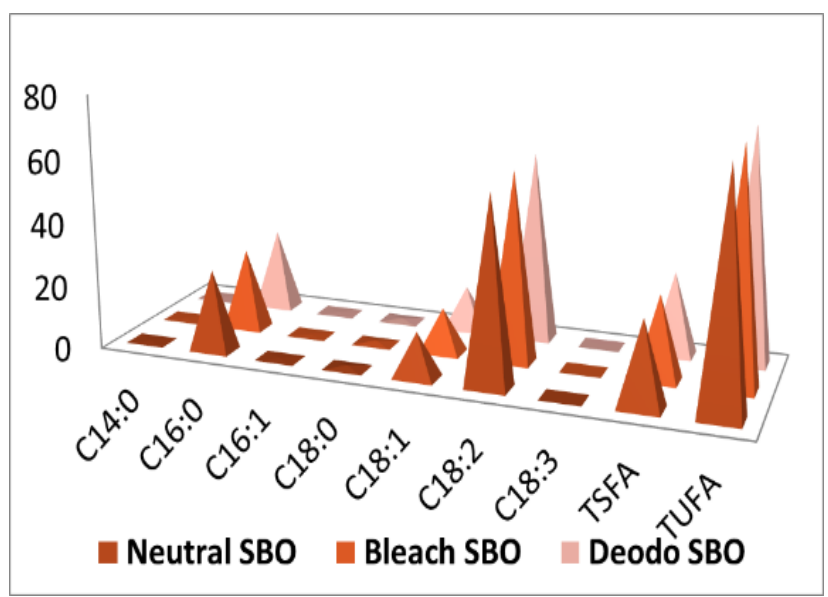

Figure 2. Fatty acid composition of soybean oil 


\subsection{Saponification value (SV)}

SV directly depends on the kinds of fatty acids present in the soybean oil. This value is also important for the soap production point of view. During industrial processing, the minor effect on SV was observed from neutralization to deodorization stages. Slight decrease of SV in crude to neutralized oil 177.0 to $176.5 \mathrm{mg} \mathrm{KOH} / \mathrm{g}$ was observed, whereas decreasing trend of SV was observed in bleaching and deodorization stages 176.5 to $176.3 \mathrm{mg} \mathrm{KOH} / \mathrm{g}$ and 176.3 to $176.1 \mathrm{mg} \mathrm{KOH} / \mathrm{g}$, respectively. Overall impact of refining was found to be $23.93 \%, 33.33 \%$ and $42.74 \%$, respectively for neutralization, bleaching and deodorization.

\subsection{Iodine value (IV)}

The degree of unsaturation of oil and fat is known as IV. It is tested by evaluating the amount of iodine (I2) reacting with a processed or natural fat within recommended conditions. It is a well-known fact that higher iodine numbers highly indicate unsaturated oil, while reverse is true for the least unsaturated oil. The IV classifies the oil as drying and non-drying oils. During refining, no significant change was observed in all stages. There was slight change in IV noticed from neutralization to deodorization 125.0 to $124.5 \mathrm{~g} \mathrm{I}_{2} / 100 \mathrm{~g}, 124.5$ to $124.2 \mathrm{~g} \mathrm{I}_{2} / 100 \mathrm{~g}$ and 124.2 to 124.1 $\mathrm{g} \mathrm{I}_{2} / 100 \mathrm{~g}$. Overall input of neutralization, bleaching and deodorization was found to be $22.72,36.36$ and $40.92 \%$, respectively.

\subsection{Peroxide value $(P V)$}

The extent level of oil or fat oxidation is measured in the quantity of peroxides existed. Peroxides are the cause of rancidity in oil. These are primary compounds formed by the oxidation of unsaturated fatty acids (Gomathi et al., 2011; Mohdaly et al., 2001). During neutralization process, no significant effect was observed on PV. On the other hand, as compared to neutralization, bleaching (Zacchi and Eggers, 2008), and deodorization stages showed somehow positive effect on PV (Shad et al., 2012). In the stage of bleaching to deodorization, $\mathrm{PV}$ was reduced from 2.0 to $1.8 \mathrm{mEq} \mathrm{O} / \mathrm{kg}$. The overall impact during refining on the removal of $\mathrm{PV}$ showed following order15.80, 39.46 and 44.74\%, respectively in neutralization, bleaching and deodorization.

\subsection{Soap content}

Salt of fatty acids in vegetable oil is known as soap content. Shelf life, quality and stability of the oil depend on the soap content, higher soap content lowers the shelf life. Soap content of crude oil was increased from 0.0 to $61.0 \mathrm{ppm}$ in the neutralization stage. On the other hand, declining trend of soap content was observed during bleaching (61.0 to 31.4 $\mathrm{ppm}$ ) and deodorization (31.4 to $15.2 \mathrm{ppm}$ ) stages. The efficiency of processing on soap content showed following trend increased $61.0 \%$, and reduced $48.50 \%$ and $27.25 \%$, respectively for neutralization, bleaching and deodorization. Overall contribution of each refining stage neutralization, bleaching and deodorization was 56.70, 29.18 and 14.12\%, respectively.

\subsection{Fatty acid composition (FAC)}

FAC compositions of SBO samples of each industrial processing stage are mentioned in Table 3 and Chart 1 . Seven different kinds of fatty acids determined in crude soyabean oil were showed in Figure 1-2. The FAC of the present study was consistent with those previously reported by IUPAC method 2.301 (Paquot and Hautfenne, 1987), for soybean oil. The total unsaturated fatty acids (UFA) and saturated fatty acids (SFA) were accounted for soybean oil as 73.89 and $26.21 \%$, respectively in the last stage of refining. The highest concentration was showed for the linoleic acid (C18:2) in soybean oil rather than myristic acid (C14:0), palmitic acid (C16:0), palmitoleic acid (C16:1), stearic acid (C18:0), oleic acid (C18:1), and linolenic acid (C18:3). Total poly unsaturated fatty acids (PUFA) are important for the fatty acid composition in edible oil, also more susceptible to oxidative rancidity (Karabulut et al. 2005; Mahesar et al., 2017). From the results of fatty acids, it seemed that industrial processing treatment had insignificant effect, except for slight decrease in the relative percentage of some fatty acids such as myristic acid, palmitic acid, palmitoleic acid, stearic acid, oleic acid, linoleic acid and linolenic acid.

\section{Conclusion}

The main impact of overall refining and individual steps i.e. neutralization, bleaching and deodorization was found to be in the reduction of color, moisture, soap content, free fatty acids, and peroxide value. However, minor effect was noticed on freezing point, smoke point, refractive index, saponification value, and iodine value. Similarly, neutralization, bleaching and deodorization showed negligible effect on the total fatty acids of the crude SBO. It can be concluded that refining processes reduced unwanted materials to safe level for the edible application and improving the quality of oil.

\section{Acknowledgement}

Authors are also thankful to Pakistan oil factory Hyderabad, Pakistan for providing industrial processed soybean oil samples. The authors are also grateful to National Centre of Excellence in Analytical Chemistry (NCEAC), University of Sindh Jamshoro, Pakistan and Erciyes University, Kayseri, Turkey for providing pleasing environment of laboratory.

\section{References}

Ali, S., Anwar, F., Ashraf, S., Talpur, F. N., \& Ashraf, M. (2009). Evaluation of canola seeds of different cultivars with special emphasis on the quantification of erucic acid and glucosinolates. Grasas y Aceites, 60(1), 89-95.

Alpaslan, M., Tepe, S., \& Simsek, O. (2001). Effect of refining processes on the total and individual tocopherol content in sunflower oil. International Journal of Food Science \& Technology, 36(7), 737-739.

Aluyor, E. O., Aluyor, P., \& Ozigagu, C. E. (2009). Effect of refining on the quality and composition of groundnut oil. African Journal of Food Science, 3(8), 201-205.

Farhoosh, R., Einafshar, S., \& Sharayei, P. (2009). The effect of commercial refining steps on the rancidity measures of soybean and canola oils. Food Chemistry, 115(3), 933-938.

Firestone, D. (2009). American Oil Chemist's Society (AOCS), 
Official and Recommended Practices of the AOCS, 6th edi., Champaign IL, Wiley, USA.

Gogolewski, M., Nogala-Kalucka, M., \& Szeliga, M. (2000). Changes of the tocopherol and fatty acid contents in rapeseed oil during refining. European journal of lipid science and technology, 102(10), 618-623.

Gomathi, R., Anusuya, N., Chitravadivu, C., \& Manian, S. (2011). Antioxidant activity of lettuce tree (Pisonia morindifolia R. Br.) and tamarind tree (Tamarindus indica L.) and their efficacy in peanut oil stability. Food Science and Biotechnology, 20(6), 1669-1677.

Hurburgh Jr, C. R. (1994). Long-term soybean composition patterns and their effect on processing. Journal of the American Oil Chemists' Society, 71(12), 1425-1427.

Hyten, D. L., Pantalone, V. R., Sams, C. E., Saxton, A. M., Landau-Ellis, D., Stefaniak, T. R., \& Schmidt, M. E. (2004). Seed quality QTL in a prominent soybean population. Theoretical and Applied Genetics, 109(3), 552-561.

Karabulut, I., Topcu, A., Yorulmaz, A., Tekin, A., \& Ozay, D. S. (2005). Effects of the industrial refining process on some properties of hazelnut oil. European journal of lipid science and technology, 107, 476-480.

Mahesar, S. A., Shah, S. N., Shirazi, S. T. H., \& Nizamani, S. M. (2017). Outcome of refining on the physicochemical properties of cottonseed oil. Pakistan Journal of Analytical \& Environmental Chemistry 18(2), 105-111.

Mohdaly, A. A. A., Sarhan, M. A., Mahmoud, A., Ramadan, M. F., \& Smetanska, I. (2010). Antioxidant efficacy of potato peels and sugar beet pulp extracts in vegetable oils protection. Food Chemistry, 123, 1019-1026.
Nichols, D. M., Glover, K. D., Carlson, S. R., Specht, J. E., \& Diers, B. W. (2006). Fine mapping of a seed protein QTL on soybean linkage group I and its correlated effects on agronomic traits. Crop Science, 46(2), 834-839.

Pagano, M. C., \& Miransari, M. (2016). The importance of soybean production worldwide. In Abiotic and biotic stresses in soybean production. Academic Press, 1-26.

Paquot, C., Hautfenne, A. (1987). International Union of Pure and Applied Chemistry, Standard Methods for the Analysis of Oils, Fats and Derivatives, 7th edi., Blackwell Scientific, London, pp. 347.

Shad, M. A., Pervez, H., Zafar, Z. I., Nawaz, H., \& Khan, H. (2012). Physicochemical properties, fatty acid profile and antioxidant activity of peanut oil. Pakistan Journal of Botany, 44(1), 435-440.

USDA, 2015. World Agricultural Production. https://apps.fas.usda.gov/psdonline/ circulars/production. Circular Series (accessed 15 August 2015).

Verleyen, T., Sosinska, U., Ioannidou, S., Verhé, R., Dewettinck, K., Huyghebaert, A., \& De Greyt, W. (2002). Influence of the vegetable oil refining process on free and esterified sterols. Journal of the American Oil Chemists' Society, 79, 947-953.

Wilcox, J. R., \& Shibles, R. M. (2001). Interrelationships among seed quality attributes in soybean. Crop Science, 41(1), 1114.

Zacchi, P., \& Eggers, R. (2008). High-temperature preconditioning of rapeseed: A polyphenol-enriched oil and the effect of refining. European Journal of Lipid Science and Technology, 110, 111-119. 